Vera Vidaković*, Miroslav Novaković, Zorica Popović, Milan Janković, Rada Matić, Vele Tešević and Srdjan Bojović

\title{
Significance of diarylheptanoids for chemotaxonomical distinguishing between Alnus glutinosa and Alnus incana
}

https://doi.org/10.1515/hf-2017-0074

Received May 12, 2017; accepted July 24, 2017; previously published online August 19, 2017

\begin{abstract}
Diarylheptanoids are a group of secondary metabolites widely distributed in the Betulaceae family and characteristic for Alnus species. In this study, the chemotaxonomic power of diarylheptanoids, such as hirsutanonol-5-O- $\beta$-D-glucopyranoside, rubranoside $\mathrm{A}$, oregonin, platyphylloside, alnuside A and hirsutanonol, has been investigated in combination with principal component analysis (PCA) for differentiation of Alnus species. Concentrations of six diarylheptanoids in the bark extracts of two natural populations of Alnus glutinosa (black alder) and Alnus incana (gray alder) were determined by ultraperformance liquid chromatography-tandem mass spectrometry (UPLC-MS/MS). PCA clearly shows the separation of three groups. Populations I (A. glutinosa) and II (A. incana) both consisted of individuals of the corresponding species. Four individuals from both sampled populations formed a separate group (population III), which possibly represents a hybrid group. Accordingly, diarylheptanoids may serve in combination with PCA as chemotaxonomic markers at the species level, which may also reveal hybrid species.
\end{abstract}

Keywords: Alnus glutinosa, Alnus incana, diarylheptanoid, hirsutanonol, linear discriminant analysis (LDA),

*Corresponding author: Vera Vidaković, Institute for Biological Research "Siniša Stanković", University of Belgrade, Bulevar Despota Stefana Street 142, Belgrade 11060, Serbia, e-mail: vera.vidakovic@ibiss.bg.ac.rs; vera.b.vidakovic@gmail.com. http://orcid.org/0000-0003-2330-208X

Miroslav Novaković: Institute of Chemistry, Technology and Metallurgy, University of Belgrade, Studentski Trg Street 12-16, Belgrade 11000 , Serbia

Zorica Popović, Rada Matić and Srdjan Bojović: Institute for Biological Research "Siniša Stanković”, University of Belgrade, Bulevar Despota Stefana Street 142, Belgrade 11060, Serbia Milan Janković and Vele Tešević: Faculty of Chemistry, University of Belgrade, Studentski Trg Street 12-16, Belgrade 11000, Serbia oregonin, platyphylloside, principal component analysis (PCA), rubranoside A, UPLC-MS/MS

\section{Introduction}

The genus Alnus Mill. (Betulaceae), commonly known as alder, is mostly distributed in the Northern Hemisphere, with the exception of a few South American species. The Alnus species occur as monoecious trees or shrubs that can be found in regions of floodplain forests or in mountains up to 2800 m a.s.l. (Krstinic et al. 2002). Alnus species are predominantly wind pollinated, and the seeds are dispersed mostly by waterways (Heuvel 2011). They enter into a symbiosis with Frankia (nitrogen-fixing actinobacteria), which enables them to grow on nitrogen-poor soil. Therefore, they play a significant role in ecosystem development because they improve the fertility of the soil and, as pioneer species help promote the growth of successional species by enriching the soil with nitrogen.

The genus Alnus includes between 20 and 35 species (Heuvel 2011; Bašić et al. 2014). Uncertainty about the number of Alnus species arises from the lack of clear morphological delimitations between taxa. Variations in leaf morphology, for example, show a continuum within and between taxa and this aggravates delimitation (Heuvel 2011). The taxonomy of Alnus is especially problematic for several species pairs or complexes, including Alnus incana (L.) Moench ssp. incana and Alnus glutinosa (L.) Gaertn., Alnus trabeculosa Hand.-Mazz. and Alnus japonica (Thunb.) Steud., and Alnus formosana (Burkill) Makino and A. japonica (Ren et al. 2010). Furthermore, species determination is complicated by hybridization and backcrossing events.

Three autochthonous alder species: A. glutinosa (L.) Gaertn., A. incana (L.) Moench, Alnus viridis (Chaix) DC., and one hybrid between A. glutinosa and A. incana, are distributed in Serbia (Vukićević 1996). A. glutinosa (black alder) is a tree up to $30 \mathrm{~m}$ in height and $40 \mathrm{~cm}$ in diameter, with dark brown cracked bark and glabrous leaves with a shape of obovate, round, emarginate or rounded-at-tip. A. incana (gray alder) is a coarse shrub or tree up to $20 \mathrm{~m}$ in 
height and $50 \mathrm{~cm}$ in diameter, with smooth gray or brown bark and egg-shaped to elliptic leaves (Banaev and Bažant 2007). The most conspicuous differences between the two species are in bark appearance and in the infructescences, which have the pedunculate form in case of black alder in contrast to the sessile form of gray alder. Hybrids between black and gray alder cannot easily be recognized based solely on morphological characteristics because of the intermediate morphology between the parents, which may be overlapping or distinctly different (Parnell 1994; Banaev and Bažant 2007).

Populations of Alnus spp. included in this study were sampled on Golija Mountain (Golija-Studenica Biosphere Reserve, UNESCO), where A. glutinosa and A. incana, as well as the hybrid between these two species were previously recorded (Vukićević and Jovanović 1983). In the period succeeding the last glacial maximum, plant species expanded from refugia and populated other ecosystems. Adaptation to new habitats over time led to great changes within taxa and to hybridization between species. This may be the reason for the evolution of great intraspecies variability in black and gray alder on Golija mountain and the occurrence of hybrids (Vukićević and Jovanović 1983).

The approach to differentiate morphologically and anatomically similar species by means of analysis of secondary metabolism products is subsumed under the keyword chemotaxonomy. The performance of chemotaxonomy was demonstrated, for example, by Sandermann (1962) for the differentiation of various Pinus species based on terpenoid compounds in the extracts, or for chemotaxonomical identification of the similar woods of true mahogany, cedar, andiroba and curupixá (Pastore et al. 2011), or for Dalbergia species via FTIR analysis of ethanol-benzene extractives (Wang et al. 2016).

Diarylheptanoids are a class of secondary metabolites with a 1,7-diphenylheptane skeleton (Figure 1), which are candidates for chemotaxonomic studies. They can have a linear or cyclic structure, and they can be diversely substituted, which contributes to their manifold appearance. A pharmaceutical relevant diarylheptanoid is curcumin, a highly bioactive diarylheptanoid from Curcuma longa (Zingiberaceae), which induces cytotoxicity in tumor cells, and curcumin acts as a chemopreventive agent exhibiting synergistic effects with anticancer drugs and developing immunostimulating, anti-inflammatory, antioxidant, neuroprotective and numerous other activities (Allegra et al. 2017; Lopresti 2017; Redondo-Blanco et al. 2017). Over 400 diarylheptanoid compounds have been isolated from species of different genera and families ( $\mathrm{Lv}$ and She 2012), and their appearance and variability is highly species specific. They are of chemotaxonomic significance for the genus Alnus and the Betulaceae family (Guz et al. 2002; Novaković et al. 2014a).

In the present study, the possibility of quantitative analysis of the secondary metabolites characteristic for Alnus species for differentiation between the Alnus taxa was investigated. The diarylheptanoid glycosides and the diarylheptanoid hirsutanonol examined herein have previously been reported as constituents of black and/or gray alder bark extracts (Martineau et al. 2010; Novaković et al.<smiles>O=C(CCc1ccc(O)c(O)c1)C[C@H](O)[C@H](O)CCc1ccc(O)c(O)c1</smiles>

Hirsutanonol-5-O- $\beta$-D-glucopyranoside<smiles>O=C(CCc1ccc(O)c(O)c1)C[C@H](O)[C@H](O)OC(=O)CCc1ccc(O)c(O)c1</smiles><smiles>O=C(CCc1ccc(O)cc1)C[C@H](CCc1ccc(O)c(O)c1)OC(O)C(O)CO</smiles>

Alnuside A

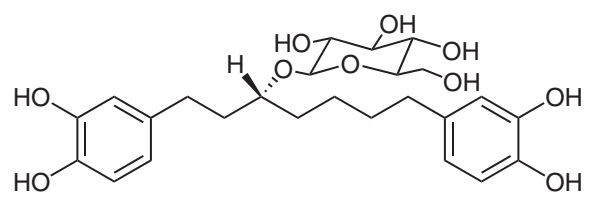

Rubranoside A<smiles>O=C(CCc1ccc(O)cc1)C[C@H](CCc1ccc(O)cc1)OC(=O)COC(O)C(O)CO</smiles>

Platyphylloside<smiles>O=C(CCc1ccc(O)c(O)c1)C[C@@H](O)CCc1ccc(O)c(O)c1</smiles>

Hirsutanonol

Figure 1: Chemical structures of diarylheptanoids investigated in this study. 
2013). In focus was the question whether diarylheptanoids are reliable indicators for (1) chemotaxonomic identification and discrimination between the species $A$. glutinosa and $A$. incana and for (2) possible hybrids between these two species.

\section{Materials and methods}

Chemicals: Substances used as standards (hirsutanonol-5- $O-\beta$-Dglucopyranoside, rubranoside A, oregonin, platyphylloside, alnuside A and hirsutanonol; Figure 1) have previously been isolated from the bark of A. glutinosa (Novaković et al. 2013). Ethanol (96\%) for extraction of plant material was freshly distilled. Solvents for ultraperformance liquid chromatography-tandem mass spectrometry (UPLC-MS/MS) analysis (chromatographic grade) were purchased from Sigma-Aldrich (St. Louis, USA).

Plant material: Field botanical determination of individuals was based on the species description, i.e. the appearance of the leaves, bark, habitus and habitat (Jovanović 2007). The bark from 42 trees of Alnus spp. was collected in the Golija-Studenica Biosphere Reserve (UNESCO-MAB) in June 2015 (Figure 2). The first population (A. glutinosa) was at the locality Rimski most $\left(43^{\circ} 28^{\prime} 09.2^{\prime \prime} \mathrm{N}, 20^{\circ} 14^{\prime} 05.9^{\prime \prime} \mathrm{E}\right)$ within a Querco-Carpinetum sensu lato (sessile oak and hornbeam forest) community. The second population (A. incana) was at the locality Sastavci $\left(43^{\circ} 27^{\prime} 38.5^{\prime \prime} \mathrm{N}, 20^{\circ} 13^{\prime} 22.0^{\prime \prime} \mathrm{E}\right)$ within a Fagetum montanum sensu lato (montane beech forest) community. The bark sampled from the populations of black and gray alder (both with $n=21$ ) were airdried at room temperature for 2 weeks and then milled into powder by an electric grinder.

Preparation of bark extracts: Powdered bark (2 g) was extracted with $96 \%$ ethanol four times $(4 \times 20 \mathrm{ml}, 24 \mathrm{~h})$ at room temperature aided by an ultrasonic bath in the last hour of each extraction. For UPLC-ESI-MS/MS analyses, the extracts were dissolved in methanol to a final concentration of $1.0 \mathrm{mg} \mathrm{ml}^{-1}$ and then filtered through a $0.45-\mu \mathrm{m}$ pore-size filter (Agilent Technologies).

UPLC Triple Quad MS-MS analysis: A stock solution of a mixture of diarylheptanoid standards (hirsutanonol-5-O- $\beta$-D-glucopyranoside, rubranoside $\mathrm{A}$, oregonin, platyphylloside, alnuside A and hirsutanonol) was prepared in methanol $(\mathrm{MeOH})$ at a concentration of $1000 \mathrm{mg} \mathrm{l}^{-1}$. Calibration solutions with concentrations of 0.0001 , $0.0010,0.0100,0.0500,0.1000$ and $0.1500 \mathrm{mg} \mathrm{ml}^{-1}$ were prepared by diluting the stock solution with $\mathrm{MeOH}$. Calibration curves were constructed based on the peak areas.

Analyses were performed with a Waters Acquity Ultra Performance $\mathrm{H}$ Class system (Waters, Milford, MA, USA). UPLC separation was realized on an Acquity UPLC BEH C18 column $(1.7 \mu \mathrm{m}$, $2.1 \mathrm{~mm} \times 150 \mathrm{~mm}$ ) equipped with a VanGuard precolumn Acquity UPLC BEH C18 $(1.7 \mu \mathrm{m}, 2.1 \mathrm{~mm} \times 5 \mathrm{~mm})$, also from Waters. The column was thermostated at $40^{\circ} \mathrm{C}$, and the flow rate was $0.3 \mathrm{ml} \mathrm{min}^{-1}$. The injection volume was $2.0 \mu \mathrm{l}$. The mobile phase consisted of $0.2 \%$ formic acid in water (solvent A) and acetonitrile (solvent B). The gradient elution program was as follows: $0-12.0 \mathrm{~min} 20-30 \% \mathrm{~B}$, $\rightarrow 12.0-12.1 \mathrm{~min} 30-100 \% \mathrm{~B}, \rightarrow 12.1-13.9 \mathrm{~min} 100 \% \mathrm{~B}, \rightarrow 13.9-14.0 \mathrm{~min}$

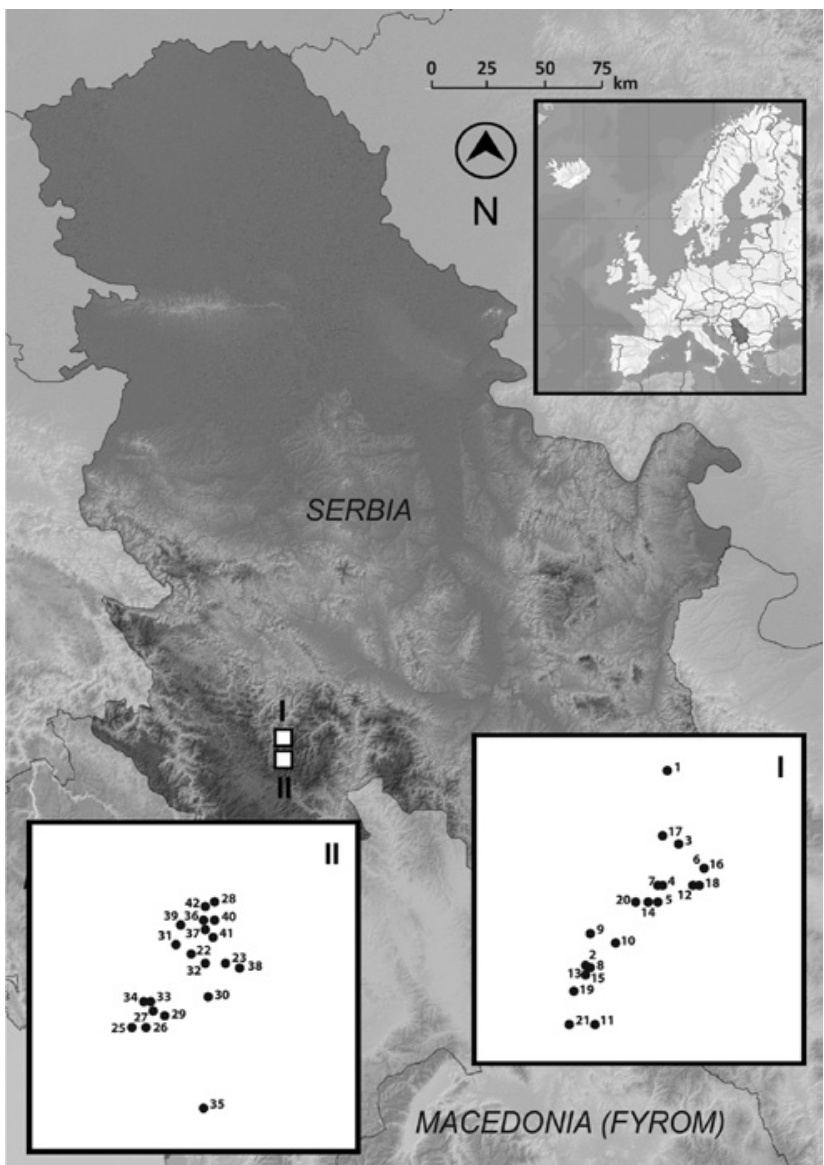

Figure 2: Locations of the studied populations: I - A. glutinosa (Rimski most: $43^{\circ} 28^{\prime} 09.2^{\prime \prime} \mathrm{N}, 20^{\circ} 14^{\prime} 05.9^{\prime \prime} \mathrm{E} ; 640 \mathrm{~m} ; n=21$ trees); II - $A$. incana (Sastavci: $43^{\circ} 27^{\prime} 38.5^{\prime \prime} \mathrm{N}, 20^{\circ} 13^{\prime} 22.0^{\prime \prime} \mathrm{E} ; 670 \mathrm{~m} ; n=21$ trees).

$100-20 \%$ B, $\rightarrow 14.0-16.0$ min $20 \%$ B. The compounds in focus were eluted within a 7 -min run time.

The UPLC was coupled to a triple quadrupole mass spectrometer Acquity TQD (Waters) equipped with the software MassLynx 4.1. The MS instrument was operated with an electrospray source in the negative ionization mode $[\mathrm{M}-\mathrm{H}]^{-}$. The ionization source conditions were as follows: capillary voltage $3.3 \mathrm{kV}$, source $150^{\circ} \mathrm{C}$, desolvation gas $450^{\circ} \mathrm{C}$, flow rate $500 \mathrm{l} \mathrm{h}^{-1}$. Nitrogen and argon served as cone and collision gases, respectively. The diarylheptanoids were analyzed by multiple reaction monitoring (MRM) (Table 1).

Statistical analysis: The assumption of normality for each variable in a given population was tested with the Shapiro-Wilk test before statistical analysis. A parametric test (ANOVA) was applied for comparing the populations when the variables appeared to follow normal distribution $(\mathrm{P}<0.05)$. A non-parametric test (Kruskal-Wallis rank sum test) was used when the variables, even after the transformation, i.e. $y^{\prime}=$ $\log _{10}(y+1)$ did not appear to follow a normal distribution. Principal component analysis (PCA) and linear discriminant analysis (LDA) were carried out to visualize the data structure in clusters. Statistical analyses were performed based on the R statistical software (version 3.2.5: The R Foundation for Statistical Computing, https://www.r-project. org/) and Statgraphics Plus (version 5.0; Statistical Graphics Corporation, USA). 
Table 1: Optimized MRM conditions for the analysis of the diarylheptanoids by UPLC-MS/MS method.

\begin{tabular}{|c|c|c|c|c|}
\hline Compound & Precursor ion $(\mathrm{m} / \mathrm{z})$ & Product ion $(\mathrm{m} / \mathrm{z})$ & Cone voltage (V) & Collision energy ( $\mathrm{V}$ ) \\
\hline Hirsutanonol-5-O- $\beta$-D-glucopyranoside & 507.35 & 327.2 & 42 & 20 \\
\hline Rubranoside A & 493.37 & 331.23 & 72 & 36 \\
\hline Oregonin & 477.34 & 327.15 & 44 & 22 \\
\hline Platyphylloside & 475.36 & 295.17 & 32 & 10 \\
\hline Alnuside A & 461.35 & 311.13 & 40 & 16 \\
\hline Hirsutanonol & 345.17 & 165.02 & 44 & 22 \\
\hline
\end{tabular}

\section{Results and discussion}

Six diarylheptanoids, namely, hirsutanonol-5-O- $\beta$-Dglucopyranoside, rubranoside $\mathrm{A}$, oregonin, platyphylloside, alnuside A and hirsutanonol, were quantified in Alnus spp. bark ethanol extracts. The sum of alnuside A and $\mathrm{B}$ was the input in further analyses, as they gave the same precursor and product ions for MRM, which could not be separated by UPLC.

PCA was performed for data evaluation and visualization (Figure 3). The first principal component (PC1) accounted for $49.7 \%$ of the total variance and the second principal component (PC2) for $17.8 \%$. According to PCA, seven variables (i.e. the concentrations of the diarylheptanoids and the yields of the extracts) rendered possible to assign the individuals into two main groups, each corresponding to one of the two species (Figure 3): population I (19 individuals of A. glutinosa, left side of the graph) and population II (19 individuals of $A$. incana, right side of the graph). The basic statistical parameters for each variable and group, based on the PCA, are presented in Figure 4. In population I, the content of hirsutanonol

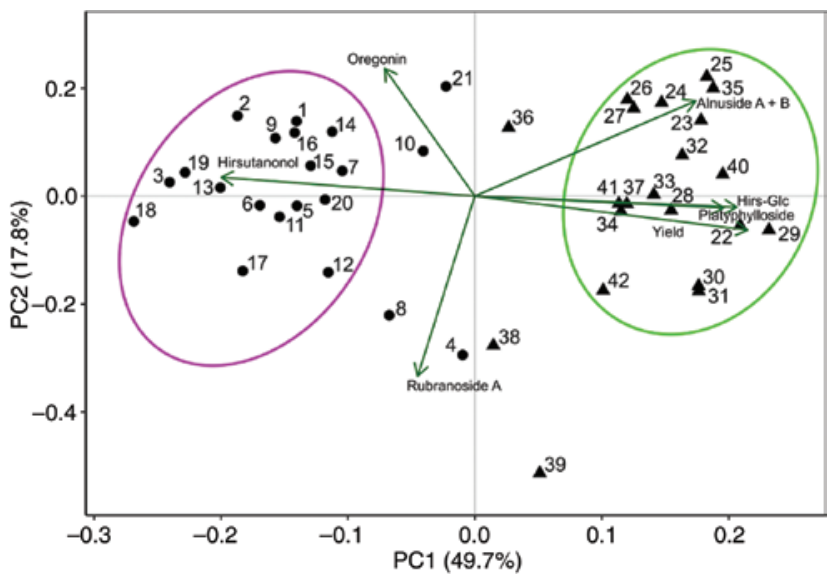

Figure 3: $P C A$ of seven variables measured from 42 trees of A. glutinosa (O) and A. incana ( $\mathbf{\Delta})$ populations. Population I, comprised of $A$. glutinosa individuals; _ population II, comprised of $A$. incana trees. was higher, whereas the extract yields and the contents of hirsutanonol-5-0- $\beta$-D-glucopyranoside and platyphylloside were lower in comparison with population II. Four individuals (4, 8, 38 and 39) formed a separate group (population III), which differs from the other groups by higher amounts of rubranoside A. Individuals 4 and 8 were identified within population I, whereas individuals 38 and 39 were located within population II. This can be interpreted that these four trees are hybrids between $A$. glutinosa and A. incana. Individuals 10, 21 and 36 formed the segregate position on the PCA graph, but they were eliminated as possible members of a group because of inconclusive representation on the discriminant axes. The differences between the three PCA groups were found to be statistically significant for each analyzed parameter (Figure 4). The differences were established by parametric or non-parametric tests, depending on the normality of the variable's distribution.

Linear discriminant analysis (LDA) was performed on the set of the three predefined groups of individuals as implied by PCA (Figure 5). The first discriminant function explained over $85 \%$ of the discrimination. The first discriminant axis mainly distinguished population II from the other groups by the higher content of hirsutanonol-5$O-\beta$-D-glucopyranoside (Figure 4). The second discriminant function mainly separated the group of four trees (population III), a possible hybrid between $A$. glutinosa and $A$. incana, from the other populations by its higher content of rubranoside A.

The occurrence of hybrids between black and gray alder is very common with sympatric species. Hybrid individuals are distributed with low frequency, around $10 \%$, because of the phenological barriers between the species: A. incana begins to blossom earlier than A. glutinosa, although the flowering periods of the species may partially overlap (Banaev and Bažant 2007; Bašić et al. 2014), but there are certainly other mechanisms of their reproductive isolation. Nevertheless, natural hybridization between these species increases genetic variation and biodiversity within the genus. Genetic variability is an important precondition for the adaptive potential of forest tree species, 

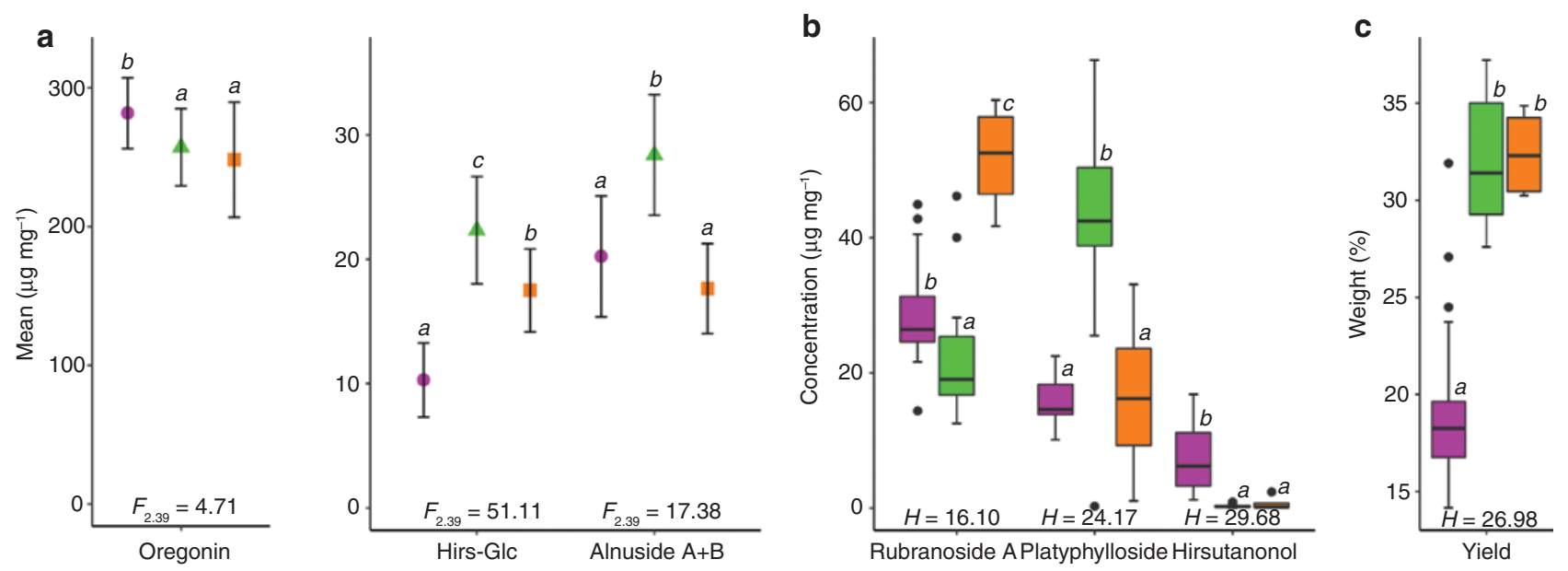

Figure 4: Comparison of three populations (_ population I, _ population II, _ population III) based on (a) mean values of concentrations of each compound ( $\mu \mathrm{g}$ of diarylheptanoid $\mathrm{mg}_{\text {of extract }}{ }^{-1}$ ), (b) median values of concentrations of each compound ( $\mu \mathrm{g}$ of diarylheptanoid $\mathrm{mg}$ of extract $\mathrm{t}^{-1}$ ) and (c) median values of yields of the extracts (\% $\left.\mathrm{w} / \mathrm{w}\right)$.

Means of the variables that followed normal distribution were compared by ANOVA $(\mathrm{P} \leq 0.05)$; $F$ values are given at the bottom of the plots with degrees of freedom; Fisher's LSD post hoc test was applied. Medians of the variables that did not follow a normal distribution were compared by Kruskal-Wallis test $(\mathrm{P} \leq 0.05) ; H$ values are given at the bottom of the plots; to determine significant differences among the medians, features of Box-and-Whisker plots of median notch were visually examined. Error bars represent mean \pm standard deviation (a) and interquartile ranges ( $\mathrm{b}$ and $\mathrm{c}$ ). Italic letters $(a, b, c)$ above the error bars and boxes indicate statistically significant differences $(\mathrm{P}<0.05)$.

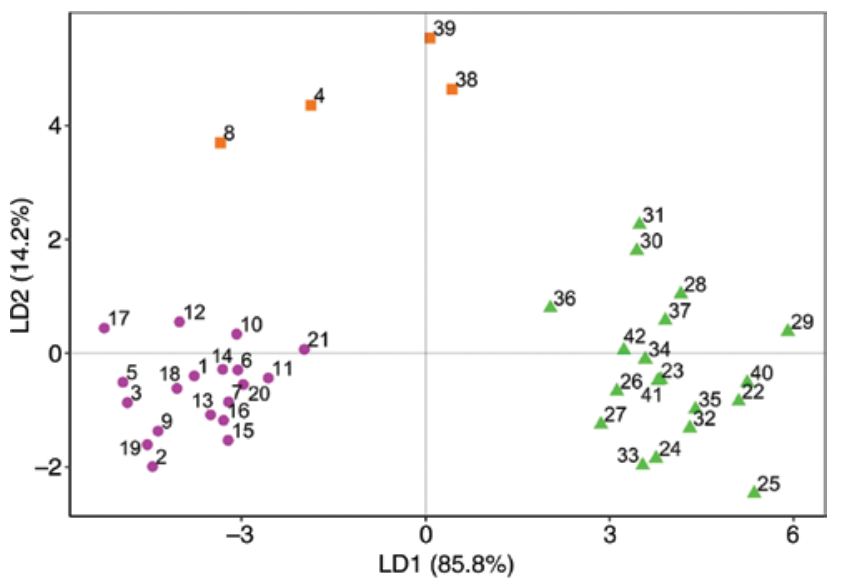

Figure 5: LDA of the three groups of Alnus spp., as indicated by PCA: (๑) population I - A. glutinosa individuals; ( $\triangle$ ) population II A. incana individuals; ( $($ ) population III - miscellaneous group.

and at a long term for the preservation of species (Poljak et al. 2014). Besides, hybrid zones represent places of high ecological and evolutionary activity that provide spots of biodiversity forming new habitats for associate living organisms (Whitham et al. 1999; Tovar-Sánchez and Oyama 2006). Based on the chemical analysis only, it cannot be stated with certainty that the trees within population III are hybrids between $A$. glutinosa and $A$. incana. Isolation of trees 4, 8, 38 and 39 on the plane of the first two PC axes, as well as trees 10, 21 and 36, could also be attributed to individual differences due to phenotypic plasticity within respective populations. The plasticity of secondary metabolism plays an essential ecological role in the dynamic interactions between plants and their diverse and continuously changing environment (Hartmann 2007). Thus, the results of the present study should be understood as a hint to perform more detailed analyses in this regard, e.g. in terms of molecular markers in combination with morphometry studies. How powerful is in the meanwhile the DNAmarker method for species identification is demonstrated by a rapidly increasing literature (e.g. Höltken et al. 2012; Yu et al. 2016).

The content of bark metabolites depends on numerous biotic and abiotic factors (Lachaud et al. 1999; Plomion et al. 2001). For these reasons, the most reliable method for analyzing the bark would be to sample within particular growth cone, but in practice this could significantly damage the tree. In this study, the outer and inner bark was sampled, trying not to damage the cambium cell layer. This sampling method may have certain limitations regarding the variability of the contents of the analyzed compounds in different individuals. However, in order to increase the reliability of the results, we strived for uniformity during sampling by selecting the mature trees of similar age, and by sampling the material on the same day, from the same height and exposition.

Diarylheptanoids and their derivatives are distributed mainly in the families Betulaceae, Zingiberaceae 
and Myricaceae, and within these families, in the genera Alnus, Betula, Alpinia, Zingiber, Curcuma and Myrica (Lv and She 2012). They can be considered as chemotaxonomic markers because oftentimes a certain genus or species is characterized by a specific type of diarylheptanoids. This is because related taxa share genes that encode enzymes, which are involved also in biosynthetic pathways of a characteristic set of secondary metabolites. On the other hand, not rarely, secondary metabolites of a substance group may also occur in unrelated taxa because of the convergent evolution of such substances or differential regulation of otherwise widely distributed genes that govern the biosynthesis of a particular secondary metabolite (Wink 2008). For example, oregonin was thus far identified only within Alnus and Corylus genera (Betulaceae) (Choi 2013; Riethmüller et al. 2016), with the exception of Pinus flexilis (Pinaceae) (Lee et al. 1998). The genera Curcuma, Alpinia and Alnus are represented mainly, but not exclusively, by the occurrence of linear diarylheptanoids (Claeson et al. 2002; Lv and She 2012), whereas cyclic diarylheptanoid derivatives are a characteristic of Myrica and Morella species (Silva et al. 2015). Substituents on the aromatic rings or on the heptane moiety usually point to distinct species. For instance, diarylheptanoids from the bark of $A$. viridis possess $p$-hydroxyphenyl aromatic groups, whereas A. glutinosa is represented by diarylheptanoids with $p$-hydroxyphenyl and/or catechol groups (Novaković et al. 2014a). Moreover, bark extracts from A. glutinosa and A. incana have similar diarylheptanoid contents (Martineau et al. 2010; Telysheva et al. 2011; Novaković et al. 2013), whereas A. viridis is in this respect closer to Betula platyphylla var. japonica (Novaković et al. 2014a), which may be significant for taxonomic considerations. Hydrophilic bark extractives of black and gray alder were found to exhibit antioxidant, cytotoxic, antimicrobial, antidiabetic and antiadipogenic activities (Spoor et al. 2006; Frédérich et al. 2009; Martineau et al. 2010; Stević et al. 2010; Telysheva et al. 2011; Dahija et al. 2014). The main constituents of these extractives are diarylheptanoids and condensed tannins. It is assumed that diarylheptanoids play an ecological role as a part of the chemical defense system against herbivores; for example, diarylheptanoid glycosides isolated from birch phloem show an inhibitory effect on ruminant digestion (Sunnerheim and Bratt 2004). Members of this group of natural products are reported to have antiviral, antimicrobial, anti-adipogenic, anti-inflammatory, cytotoxic and many other activities (Mshvildadze et al. 2007; Tung et al. 2010; Lai et al. 2012; Lee et al. 2013; Novaković et al. 2014b, 2015).

\section{Conclusions}

Quantification of the most abundant alder diarylheptanoids in bark extracts was used for the first time for differentiation between the species A. glutinosa and A. incana. Diarylheptanoids proved to be good chemotaxonomic markers at the interspecific level. It was demonstrated that diarylheptanoids are reliable indicators for the identification and discrimination between the species A. glutinosa and $A$. incana. The analytical power of this approach for differentiation of hybrids needs to be verified by further research including genetic studies.

Acknowledgements: This research was supported financially by the Serbian Ministry of Education, Science and Technological Development, Project Nos. 173011 and 172053.

\section{References}

Allegra, A., Innao, V., Russo, S., Gerace, D., Alonci, A., Musolino, C. (2017) Anticancer activity of curcumin and its analogues: preclinical and clinical studies. Cancer Invest. 35:1-22.

Banaev, E.V., Bažant, V. (2007) Study of natural hybridization between Alnus incana (L.) Moench. and Alnus glutinosa (L.) Gaertn. J. For. Sci. 53:66-73.

Bašić, N., Selimović, E., Pustahija, F. (2014) Morphological identification of nothospecies Alnus $\times$ pubescens Tausch. and their new localities in central Bosnia. Works Fac. For., Univ. Sarajevo 44:15-24.

Choi, S.E. (2013) Chemotaxonomic significance of oregonin in Alnus species. Asian J. Chem. 25:6989-6990.

Claeson, P., Claeson, U.P., Tuchinda, P., Reutrakul, V. (2002) Occurrence, structure and bioactivity of 1,7-diarylheptanoids. Stud. Nat. Prod. Chem. 26:881-908.

Dahija, S., Čakar, J., Vidic, D., Maksimović, M., Parić, A. (2014) Total phenolic and flavonoid contents, antioxidant and antimicrobial activities of Alnus glutinosa (L.) Gaertn., Alnus incana (L.) Moench and Alnus viridis (Chaix) DC. extracts. Nat. Prod. Res. 28:2317-2320.

Frédérich, M., Marcowycz, A., Cieckiewicz, E., Mégalizzi, V., Angenot, L., Kiss, R. (2009) In vitro anticancer potential of tree extracts from the Walloon Region forest. Planta Med. 75:1634-1637.

Guz, N.R., Lorenz, P., Métraux, J.-P. (2002) Oregonin from the bark of European Alnus species. Biochem. Syst. Ecol. 30:471-474.

Hartmann, T. (2007) From waste products to ecochemicals: fifty years research of plant secondary metabolism. Phytochemistry 68:2831-2846.

Heuvel, B.D.V. (2011) Alnus. In: Wild Crop Relatives: Genomic and Breeding Resources - Forest Trees. Ed. Kole, C. Springer, Berlin Heidelberg. pp. 1-14.

Höltken, A.M., Schröder, H., Wischnewski, N., Degen, B., Magel, E., Fladung, M. (2012) Development of DNA-based methods to identify CITES-protected timber species: a case study in the Meliaceae family. Holzforschung 66:97-104. 
Jovanović, B. Dendrologija. Šumarski fakultet, Beograd, 2007.

Krstinic, A., Gracan, J., Kajba, D. (2002) Alnus spp. genetic resources conservation strategy. In: Noble Hardwoods Network, Report of the fourth meeting, 4-6 September 1999, Gmunden, Austria, and the fifth meeting, 17-19 May 2001, Blessington, Ireland. Eds. Turok, J., Eriksson, G., Russell, K., Borelli, S. International Plant Genetic Resources Institute, Rome, Italy. pp. 44-49.

Lachaud, S., Catesson, A.-M., Bonnemain, J.-L. (1999) Structure and functions of the vascular cambium. C. R. Acad. Sci., Ser. III 322:633-650.

Lai, Y.-C., Chen, C.-K., Lin, W.-W., Lee, S.-S. (2012) A comprehensive investigation of anti-inflammatory diarylheptanoids from the leaves of Alnus formosana. Phytochemistry 73:84-94.

Lee, K.K., Bahler, B.D., Hofmann, G.A., Mattern, M.R., Johnson, R.K., Kingston, D.G.I. (1998) Isolation and structure elucidation of new PKC $\alpha$ inhibitors from Pinus flexilis. J. Nat. Prod. 61:1407-1409.

Lee, M., Song, J.Y., Chin, Y.-W., Sung, S.H. (2013) Anti-adipogenic diarylheptanoids from Alnus hirsuta f. sibirica on 3T3-L1 cells. Bioorg. Med. Chem. Lett. 23:2069-2073.

Lopresti, A.L. (2017) Curcumin for neuropsychiatric disorders: a review of in vitro, animal and human studies. J. Psychopharmacol. (Oxf.) 31:287-302.

Lv, H., She, G. (2012) Naturally occurring diarylheptanoids a supplementary version. Rec. Nat. Prod. 6:321-333.

Martineau, L.C., Hervé, J., Muhamad, A., Saleem, A., Harris, C.S., Arnason, J.T., Haddad, P.S. (2010) Anti-adipogenic activities of Alnus incana and Populus balsamifera bark extracts, part I: sites and mechanisms of action. Planta Med. 76:1439-1446.

Mshvildadze, V., Legault, J., Lavoie, S., Gauthier, C., Pichette, A. (2007) Anticancer diarylheptanoid glycosides from the inner bark of Betula papyrifera. Phytochemistry 68:2531-2536.

Novaković, M., Stanković, M., Vučković, I., Todorović, N., Trifunović, S., Tešević, V., Vajs, V., Milosavljević, S. (2013) Diarylheptanoids from Alnus glutinosa bark and their chemoprotective effect on human lymphocytes DNA. Planta Med. 79:499-505.

Novaković, M., Stanković, M., Vučković, I., Todorović, N., Trifunović, S., Apostolović, D., Mandić, B., Veljić, M., Marin, P., Tešević, V., Vajs, V., Milosavljević, S. (2014a) Diarylheptanoids from green alder bark and their potential for DNA protection. Chem. Biodivers. 11:872-885.

Novaković, M., Pešić, M., Trifunović, S., Vučković, I., Todorović, N., Podolski-Renić, A., Dinić, J., Stojković, S., Tešević, V., Vajs, V., Milosavljević, S. (2014b) Diarylheptanoids from the bark of black alder inhibit the growth of sensitive and multi-drug resistant non-small cell lung carcinoma cells. Phytochemistry 97:46-54.

Novaković, M., Novaković, I., Cvetković, M., Sladić, D., Tešević, V. (2015) Antimicrobial activity of the diarylheptanoids from the black and green alder. Braz. J. Bot. 38:441-446.

Parnell, J.A.N. (1994) Variation and hybridisation of Alnus Miller in Ireland. Watsonia 20:67-70.

Pastore, T.C.M., Braga, J.W.B., Coradin, V.T.R., Magalhães, W.L.E., Okino, E.Y.A., Camargos, J.A.A., de Muñiz, G.I.B., Bressan, O.A., Davrieux, F. (2011) Near infrared spectroscopy (NIRS) as a potential tool for monitoring trade of similar woods: discrimination of true mahogany, cedar, andiroba, and curupixá. Holzforschung 65:73-80.

Plomion, C., Leprovost, G., Stokes, A. (2001) Wood formation in trees. Plant Physiol. 127:1513-1523.
Poljak, I., Idžojtić, M., Šapić, I., Vukelić, J., Zebec, M. (2014) Population variability of gray (Alnus incana/L./Moench) and black alder (A. glutinosa /L./ Gaertn.) in the Mura and Drava region according to the leaf morphology. Šum. list 138:7-17.

Redondo-Blanco, S., Fernández, J., Gutiérrez-del-Río, I., Villar, C.J., Lombó, F. (2017) New insights toward colorectal cancer chemotherapy using natural bioactive compounds. Front. Pharmacol. 8:109.

Ren, B.-Q., Xiang, X.-G., Chen, Z.-D. (2010) Species identification of Alnus (Betulaceae) using nrDNA and cpDNA genetic markers. Mol. Ecol. Resour. 10:594-605.

Riethmüller, E., Könczöl, Á., Szakál, D., Végh, K., Balogh, G.T., Kéry, Á. (2016) HPLC-DPPH screening method for evaluation of antioxidant compounds in Corylus species. Nat. Prod. Commun. 11:641-644.

Sandermann, W. (1962) Biosynthetische Untersuchungen an verschiedenen Kiefernarten. Holzforschung 16:65-74.

Silva, B.J.C., Seca, A.M.L., Barreto, M. do C., Pinto, D.C.G.A. (2015) Recent breakthroughs in the antioxidant and anti-inflammatory effects of Morella and Myrica species. Int. J. Mol. Sci. 16:17160-17180.

Spoor, D.C.A., Martineau, L.C., Leduc, C., Benhaddou-Andaloussi, A., Meddah, B., Harris, C., Burt, A., Fraser, M.-H., Coonishish, J., Joly, E., Cuerrier, A., Bennett, S.A.L., Johns, T., Prentki, M., Arnason, J.T., Haddad, P.S. (2006) Selected plant species from the Cree pharmacopoeia of northern Quebec possess antidiabetic potential. Can. J. Physiol. Pharmacol. 84:847-858.

Stević, T., Šavikin, K., Zdunić, G., Stanojković, T., Juranić, Z., Janković, T., Menković, N. (2010) Antioxidant, cytotoxic, and antimicrobial activity of Alnus incana (L.) ssp. incana Moench and $A$. viridis (Chaix) DC ssp. viridis extracts. J. Med. Food 13:700-704.

Sunnerheim, K., Bratt, K. (2004) Identification of centrolobol as the platyphylloside metabolite responsible for the observed effect on in vitro digestibility of hay. J. Agric. Food Chem. 52:58695872.

Telysheva, G., Dizhbite, T., Bikovens, O., Ponomarenko, J., Janceva, S., Krasilnikova, J. (2011) Structure and antioxidant activity of diarylheptanoids extracted from bark of grey alder (Alnus incana) and potential of biorefinery-based bark processing of European trees. Holzforschung 65:623-629.

Tovar-Sánchez, E., Oyama, K. (2006) Effect of hybridization of the Quercus crassifolia $\times$ Quercus crassipes complex on the community structure of endophagous insects. Oecologia 147:702-713.

Tung, N.H., Kwon, H.-J., Kim, J.-H., Ra, J.C., Ding, Y., Kim, J.A., Kim, Y.H. (2010) Anti-influenza diarylheptanoids from the bark of Alnus japonica. Bioorg. Med. Chem. Lett. 20: 1000-1003.

Vukićević, E. Dekorativna dendrologija. Šumarski fakultet, Beograd, 1996.

Vukićević, E., Jovanović, B. (1983) Contribution to the taxonomic study of black and gray alder in the surrounding of Sjenica. Bull. Coll. For., Univ. Belgrade 61:1-14.

Wang, S.-N., Zhang, F.-D., Huang, A.-M., Zhou, Q. (2016) Distinction of four Dalbergia species by FTIR, 2nd derivative IR, and 2D-IR spectroscopy of their ethanol-benzene extractives. Holzforschung 70:503-510.

Whitham, T.G., Martinsen, G.D., Keim, P., Floate, K.D., Dungey, H.S., Potts, B.M., Keim, P. (1999) Plant hybrid zones affect biodiver- 
sity: tools for a genetic-based understanding of community structure. Ecology 80:416-428.

Wink, M. (2008) Plant secondary metabolism: diversity, function and its evolution. Nat. Prod. Commun. 3:1205-1216.
Yu, M., Liu, K., Zhou, L., Zhao, L., Liu, S. (2016) Testing three proposed DNA barcodes for the wood identification of Dalbergia odorifera T. Chen and Dalbergia tonkinensis Prain. Holzforschung 70:127-136. 